\title{
OPTIMALISASI PROGRAM PENDIDIKAN PENCEGAHAN DAN PENGURANGAN RISIKO BENCANA DI SD NEGERI UMBULHARJO 2 CANGKRINGAN
}

\section{THE OPTIMISE OF DISASTER RISK REDUCTION AND PREVENTION EDUCATION PROGRAM IN UMBULHARJO 2 CANGKRINGAN ELEMENTARY SCHOOL}

\author{
Safira Faiz Indarti \\ Filsafat dan Sosiologi Pendidikan FIP UNY \\ firaindarti@gmail.com
}

\begin{abstract}
Abstrak
Penelitian ini bertujuan untuk mengetahui pengoptimalan dalam pelaksanaan program pendidikan pencegahan dan pengurangan risiko bencana pada sekolah siaga bencana di SD Negeri Umbulharjo 2 Cangkringan-Sleman. Penelitian ini menggunakan pendekatan kualitatif metode deskriptif. Pengumpulan data dilakukan menggunakan observasi, wawancara, dan dokumentasi. Teknik analisis data menggunakan model analisis data interaktif Miles dan Huberman. Adapun teknik keabsahan data menggunakan triangulasi teknik dan triangulasi sumber. Hasil penelitian ini menunjukkan bahwa SD Negeri Umbulharjo 2 Cangkringan-Sleman telah memenuhi efektivitas program melalui ketepatan sasaran yakni siswa, kemudian sosialisasi program dilaksanakan melalui pelatihan guru, simulasi bencana, dan kerjasama dengan pihak lain, lalu ketercapaian tujuan program dilaksanakan oleh sekolah melalui misi, tujuan, dan integrasi ke dalam kurikulum sekolah, dan terakhir untuk pemantauan program bergantung pada monitoring dan evaluasi dari pemerintah. Sekolah ini telah memenuhi efisiensi program dengan memanfaatkan sumber daya manusia dalam pelaksanaanya melalui pembentukan Tim Sekolah Siaga Bencana dan bekerjasama dengan masyarakat sekitar.
\end{abstract}

Kata kunci: Optimalisasi, Pencegahan dan Pengurangan Risiko Bencana, Sekolah Siaga Bencana

\begin{abstract}
The aim of this research is finding out the optimise of disaster risk reduction and prevention education program in Umbulharjo 2 Cangkringan-Sleman Elementary School. This research is using a qualitative approach with a descriptive method. Observation, interview, and documentation are using for collect the data. Miles and Huberman models is using for analyse the data. As for the data validity using data triangulation. This research indicate that school get efectiveness by the accuracy of targeting students. Then, the program socialization was carried out by teacher's training, disaster simulatiions, and collaboration with another institution. The aim of program was carried out by the school mission, school goals, and integration into the school curriculum. The monitoring and evaluation of this program depend on government. This school get efficiency of the program from human resources. The utilization of human resources was developing Sekolah Siaga Bencana team and collaborated with society.
\end{abstract}

Keywords: Optimise, Disaster Risk Reduction and Prevention Education Program 


\section{PENDAHULUAN}

Indonesia merupakan negara yang rawan akan terjadinya bencana, baik bencana alam maupun bencana nonalam. Indonesia terletak pada pertemuan tiga lempeng tektonik yakni lempeng Indo- Australia, lempeng Eurasia dan lempeng Pasifik yang aktivitasnya menghasilkan peningkatkan aktivitas gunung api serta menghasilkan gempa dengan intensitas yang cukup tinggi di Indonesia (Sayidatun Nisa, 2019). Pendidikan merupakan hak seluruh warga negara Indonesia sebagai upaya untuk memanusiakan manusia yang harus dilengkapi dengan wawasan dan pengetahuan akan pentingnya menyelamatkan diri apabila terjadi gunung meletus, gempa bumi, tsunami, banjir, longsor, dan bencana alam lainnya. Pendidikan mengenai kebencanaan adalah suatu cara yang dilakukan untuk menciptakan pengetahuan yang baik, situasi yang aman, dan sikap yang tangguh dalam menghadapi bencana yang dilakukan dengan memberikan pendidikan kebencanaan pada semua level pendidikan baik formal maupun informal (Septikasari \& Ayriza, 2018). Pengenalan awal bencana dan ekosistem yang ada di lingkungan sekitar tempat tinggal anak-anak merupakan media nyata yang bisa digarap dan diberikan untuk para generasi muda dalam membentuk kesiapsiagaan menghadapi bencana (Widjanarko \& Minnafiah, 2018). Hal ini sangat berguna bagi kehidupan peserta didik, baik saat maupun telah selesai mendapatkan pendidikan formal di sekolah. Namun, banyak sekolah di Indonesia belum memperhatikan tentang pentingnya hal tersebut. Mengacu pada data Sekretariat Nasional Satuan Pendidikan Aman Bencana Kementerian Pendidikan dan Kebudayaan, pada Tsunami Aceh tahun 2004 terdapat 2000 sekolah rusak dan 220.000 korban meninggal dan hilang. Gempa Yogyakarta tahun 2006 terdapat 2900 sekolah terdampak dan 6000 korban meninggal. Letusan Gunung Merapi pada tahun 2010 berimbas pada 11 sekolah yang rusak. Banjir Jakarta tahun 2013 berdampak pada 251 sekolah dan 70.270 peserta didik. Letusan Gunung Sinabung tahun 2014 berdampak pada 185 sekolah dan 2856 peserta didik mengungsi. Gempa Lombok tahun 2018 terdapat 606 sekolah rusak. Gempa dan Tsunami Palu di akhir tahun 2018 merenggut 375 peserta didik dan merusak 1299 sekolah.

Sekolah memiliki peran yang sangat strategis dalam pencegahan dan pengurangan risiko bencana. Sekolah Siaga Bencana adalah program yang dimiliki Indonesia yang menerapkan program 
kesiapsiagaan terhadap bencana di daerahdaerah rawan bencana di sekolah. Sekolah Siaga Bencana merupakan sekolah yang sekolah yang memiliki kemampuan untuk mengelola risiko bencana di lingkungannya (Konsorium Pendidikan Bencana Indonesia, 2011). Pada Sekolah Siaga Bencana terdapat tiga pilar penting yang menjadi kunci keberhasilan Sekolah Siaga Bencana, yakni Fasilitas Sekolah Aman, Manajemen Bencana di Sekolah, dan Pendidikan Pencegahan dan Pengurangan Risiko Bencana (Amri, 2017). Tiga pilar tersebut merupakan hal pokok yang di beberapa Sekolah Siaga Bencana masih belum maksimal dalam pelakasanaannya.

Pilar pertama dalam Sekolah Siaga Bencana adalah fasilitas sekolah aman. Bangunan dan fasilitas sekolah yang tidak aman dari bencana sangat rentan dari segi keamanan, mengancam jiwa, merusak sarana dan prasarana yang berarti menghilangkan aset negara dan biaya untuk membangun ulang akan membebani perekonomian negara. Manajemen bencana di sekolah merupakan pilar kedua yang merupakan proses pengkajian yang diikuti oleh perencanaan terhadap perlindungan fisik, perencanaan pengembangan kapasitas dalam melakukan tanggap darurat, dan perencanaan kesinambungan pendidikan di tingkat sekolah sampai otoritas pendidikan di kabupaten/kota, provinsi hingga nasional. Berdasarkan penelitian dari Setiawati, sekolah telah melaksanakan manajemen mitigasi bencana melalui program Sekolah Siaga Bencana akan tetapi dalam prakteknya kurang maksimal dikarenakan banyaknya program oleh pemerintah untuk sekolah yang mengakibatkan fokus sekolah dalam melakasanakan program Sekolah Siaga Bencana menjadi terbagi-bagi (Setiawati, 2019). Pendidikan Pencegahan dan Pengurangan Risiko Bencana merupakan pilar ketiga dalam menyangga keberhasilan Sekolah Siaga Bencana. Pendidikan Pencegahan dan Pengurangan Risiko Bencana (PRB) merupakan kegiatan jangka panjang yang mengupayakan pengurangan risiko bencana dapat mencapai sasaran yang lebih luas dan dapat dikenal lebih dini oleh seluruh peserta didik, sehingga menumbuhkan kesiapsiagaan individu dan masyarakat dalam menghadapi bencana (Rahma, 2018). Pembelajaran tentang pengurangan risiko bencana yang telah dilaksanakan sekarang hanya berupa tema yang disiapkan pada mata pelajaran lain, sehingga hasilnya masih belum optimal (Desfandi, 2014).

SD Negeri Umbulharjo 2 Cangkringan-Sleman merupakan salah satu 
piloting project Sekolah Siaga Bencana yang dibentuk oleh pemerintah pada tahun 2014 . Sekolah ini berada pada radius $10 \mathrm{~km}$ dari Gunung Merapi. Berdasarkan hal tersebut perlu adanya penelitian untuk mengetahui optimalisasi program pendidikan pencegahan dan pengurangan risiko bencana pada SD Negeri Umbulharjo 2 CangkringanSleman ini.

\section{METODE PENELITIAN}

Jenis Penelitian

Penelitian berjudul "Optimalisasi Program Pendidikan Pencegahan dan Pengurangan Risiko Bencana Pada Sekolah Siaga Bencana di SD Negeri Umbulharjo 2 Cangkringan-Sleman" ini dilakukan melalui pendekatan penelitian kualitatif kemudian ditulis secara deskriptif. Sehingga dalam penelitian ini, peneliti menuliskan hasil penulisan dalam bentuk deskriptif berupa kata-kata yang sesuai dengan sistematika penelitian. Dalam penelitian yang dilakukan secara kualitatif deskriptif ini, peneliti bermaksud untuk mengetahui keoptimalan program pendidikan pencegahan dan pengurangan risiko bencana di SD Negeri Umbulharjo 2 Cangkringan-Sleman. Diharapkan dengan menggunakan pendekatan penelitian kualitatif deskriptif, peneliti dapat menjelaskan hasil penelitian secara lebih rinci.

\section{Waktu dan Tempat Penelitian}

Penelitian ini dilaksanakan di SD Negeri Umbulharjo 2 Kecamatan Cangkringan, Kabupaten Sleman, Provinsi Daerah Istimewa Yogyakarta. Waktu penelitian dilaksanakan pada bulan FebruariApril 2020.

\section{Subjek Penelitian}

Subjek penelitian merupakan orangorang yang menjadi sumber informasi yng dapat memberikan data sesuai dengan masalah yang sedang diteliti. Dalam penelitian ini peneliti menggunakan teknik purposive sampling. Narasumber yang dipilih berdasarkan pertimbangan- pertimbangan tertentu dan dianggap paling memahami program pendidikan pencegahan dan pengurangan risiko bencana. Narasumber dalam penelitian ini yaitu 1 kepala sekolah, 1 guru, dan 7 siswa.

\section{Teknik Pengumpulan Data}

Pada penlitian ini metode yang digunakan untuk mengumpulkan data adalah triangulasi. Triangulasi dalam mengumpulkan data terdiri dari observasi, wawancara, dan dokumentasi.

\section{Instrumen Penelitian}

Penelitian ini dilakukan dengan menggunakan instrumen penelitian 
berdasarkan teknik triangulasi dalam pengumpulan data, yakni:

1. Pedoman Observasi

Digunakan untuk menjaring data dan fasilitas yang berkaitan dengan program pendidikan pencegahan dan pengurangan risiko bencana pada sekolah siaga bencana di SD Negeri Umbulharjo 2 CangkringanSleman.

\section{Pedoman Wawancara}

Pedoman wawancara digunakan untuk memperoleh data informasi terkait dengan proses pengoptimalan program pendidikan pencegahan dan pengurangan risiko bencana pada sekolah siaga bencana di SD Negeri Umbulharjo 2 CangkringanSleman.

\section{Pedoman Dokumentasi}

Dokumentasi digunakan untuk memperoleh data mengenai pelaksanaan kegiatan dan segala sumber yang mendukung program pendidikan pencegahan dan pengurangan risiko bencana pada sekolah siaga bencana di SD Negeri Umbulharjo 2 Cangkringan-Sleman.

\section{Teknik Analisis Data}

Analisa data dalam penelitian ini menggunakan analisis interaktif Miles \& Huberman (1992) yang terdapat tiga tahapan dalam menganalisis data, yakni reduksi data, penyajian data, dan penarikan kesimpulan.
Pada penelitian ini reduksi data digunakan untuk menyortir hasil dari penelitian yang diperlukan saja. Kemudian data yang telah direduksi tersebut disajikan dalam bentuk uraian deksriptif. Tahap terakhir adalah penarikan kesimpulan dimana hasil dari data yang direduksi lalu disajikan maka peneliti dapat menarik kesimpulan dari hasil penelitian ini.

\section{Keabsahan Data}

Teknik triangulasi data digunakan dalam penelitian ini untuk menguji keabsahan data yang didapatkan supaya benar-benar sesuai dengan tujuan dan maksud penelitian. Pada penelitian ini penggunaan triangulasi teknik dan triangulasi sumber sebagai teknik keabsahan data dilakukan dengan mengomparasikan data hasil wawancara, observasi, dan dokumentasi.

\section{HASIL PENELITIAN DAN \\ PEMBAHASAN}

Optimalisasi Program Pendidikan dan Pencegahan Risiko Bencana di SD Negeri Umbulharjo 2 Cangkringan - Sleman

\section{Efektivitas Program}

Efektivitas dalam pelaksanaan program pendidikan pencegahan dan pengurangan risiko bencana yang dilaksanakan oleh SD Negeri Umbulharjo 2 Cangkringan-Sleman ini diukur dalam 
empat unsur yang menentukan tingkat efektivitas sebuah program, yakni ketepatan sasaran, sosialisasi program, ketercapaian tujuan, dan pemantauan program (Budiani, 2007).

a. Ketepatan Sasaran Program

Sasaran utama dari program pendidikan pencegahan dan pengurangan risiko bencana ini adalah siswa. Ketika siswa mendapatkan pembelajaran dan pembiasaan tentang pentingnya pencegahan dan pengurangan risiko bencana, harapannya ketika suatu saat terjadi bencana siswa sudah siap siaga dan mampu mencegah dan mengurangi risiko bencana minimal untuk dirinya sendiri. Menurut salah satu guru yang menjadi narasumber, siswa jauh lebih mudah bangkit ketika terjadi musibah, orang tua terkadang masih sering merasa trauma. Ketika Gunung Merapi erupsi beberapa waktu terakhir, traumanya masih dirasakan seperti erupsi Gunung Merapi pada tahun 2010. Program pendidikan pencegahan dan pengurangan risiko bencana bagi warga sekolah merupakan sebuah kewajiban yang harus menjadi budaya dalam kehidupan sehari-hari. Sikap untuk selalu siap, siaga, tangguh, dan tidak panik ketika terjadi bencana harus juga harus dikuasai oleh guru dan tenaga kependidikan. Selain itu siswa sudah terbiasa dengan aktivitas Gunung
Merapi karena terbentuk dengan sendirinya oleh lingkungan tempat tinggal yang terdampak secara langsung maupun tidak langsung. Kepala sekolah menjelaskan bahwa kesiapan siswa dalam menghadapi bencana diberikan melalui pembelajaran dari pengalaman pada masa lalu.

b. Sosialisasi Program

Proses sosialisasi dalam program pendidikan pencegahan dan pengurangan risiko bencana pada SD Negeri Umbulharjo 2 Cangkringan-Sleman dimulai dan dipersiapkan sejak sekolah ini resmi menjadi Sekolah Siaga Bencana. Sekolah ini merupakan salah satu dari beberapa sekolah di Provinsi Daerah Istimewa Yogyakarta yang dicanangkan pertama kali menjadi Sekolah Siaga Bencana pada tahun 2014. Sekolah ini melaksanakan sosialisasi program pendidikan pencegahan dan pengurangan risiko bencana dimulai sejak dicanangkan menjadi Sekolah Siaga Bencana pada tahun 2012 dan diresmikan pada tahun 2014, kemudian sekolah mengikuti pelatihan untuk guru dan tenaga kependidikan yang dilaksanakan oleh BPBD. Setelahnya sekolah melakasanakan simulasi secara rutin sebanyak dua kali dalam satu tahun ajaran, dan dilaksanakan simulasi apabila ada tamu dari luar sekolah menghendaki adanya simulasi bencana. 
Selain itu dalam evakuasi apabila terjadi bencana, sekolah telah memiliki MOU dengan sekolah lain untuk melaksanakan proses pembelajaran. Berdasarkan penjelasan di atas sosialisasi program pendidikan pencegahan dan pengurangan risiko bencana pada SD Negeri Umbulharjo

2 Cangkringan-Sleman cukup baik karena berusaha menjaring beberapa pihak dalam prosesnya.

c. Ketercapaian Tujuan Program

Ketercapaian tujuan dari program

pendidikan pencegahan dan pengurangan risiko bencana ini adalah terwujudnya budaya siap dan siaga dalam menghadapi ancaman bencana. Tujuan ini dilaksanakan oleh SD Negeri Umbulharjo 2 CangkringanSleman melalui misi dan tujuan sekolah. Selain itu kurikulum pembelajaran yang disusun sekolah ini juga memuat kurikulum khusus pendidikan mitigasi bencana guna mewujudkan tujuan dari program pendidikan pencegahan dan pengurangan risiko bencana.

\section{d. Pemantauan Program}

Pemantauan program dalam pendidikan pencegahan dan pengurangan risiko bencana yang dilaksanakan oleh SD Negeri Umbulharjo 2 ini bergantung pada monitoring dan evaluasi dari pemerintah. Monitoring dan evaluasi untuk pelaksanaan program pendidikan pencegahan dan pengurangan risiko bencana di SD Negeri Umbulharjo 2 Cangkringan - Sleman ini biasanya dilaksanakan serentak oleh beberapa Sekolah Siaga Bencana dari berbagai tingkatan di Kecamatan Cangkringan dan Kecamatan Pakem, kemudian dikumpulkan di kantor BPBD Pakem.

\section{Efisiensi Program}

Efisiensi sering dikaitkan dengan kinerja suatu organisasi karena efisiensi mencerminkan perbandingan antara keluaran (output) dengan masukan (input) (Ritaudin, 2015). Perbandingan antara output yang dihasilkan terhadap input yang digunakan merupakan hal yang digunakan untuk mengukur efisiensi. Proses kegiatan operasional sebuah program dapat dikatakan efisien apabila program tersebut dapat dicapai dengan menggunakan sumber daya dan dana yang serendah-rendahnya.

\section{a. Pemanfaatan Sumber Daya}

Sumber daya terbesar yang dimiliki dan dimanfaatkan dengan baik oleh sekolah ini adalah sumber daya manusia (SDM). Sumber daya manusia adalah orang-orang yang ada dalam organisasi dan memberikan sumbangan pemikiran serta melakukan berbagai jenis pekerjaan dalam mencapai tujuan organisasi (Sukirno, 2006). SDM 
dalam program pendidikan pencegahan dan pengurangan risiko bencana di SD Negeri Umbulharjo 2 Cangkringan-Sleman ini terdiri dari SDM internal dan SDM eksternal. SDM internal terdiri dari kepala sekolah, guru, dan karyawan dan SDM eksternal terdiri dari masyarakat yang tinggal disekitar sekolah dan relawan yang telah ditugaskan untuk mengevakuasi masyarakat di Kecamatan Cangkringan. SDM internal di sekolah ini dibentuk menjadi Tim Sekolah Siaga Bencana yang berfungsi sebagai garda terdepan dalam melaksanakan program pendidikan pencegahan dan pengurangan risiko bencana. Berikut Tim Sekolah Siaga Bencana SD Negeri Umbulharjo 2 Cangkringan-Sleman.

Tabel 1. Daftar Tim Sekolah Siaga Bencana

\begin{tabular}{|c|c|c|}
\hline NO & KELOMPOK & ANGGOTA \\
\hline 1 & Pos Komando & $\begin{array}{l}\text { - Nunuk Kistyawati, } \\
\text { M.Pd (Kepala } \\
\text { Sekolah/ } \\
\text { Komandan) } \\
\text { - Suparno, S.Pd } \\
\text { (Wakil Komandan) } \\
\text { - Zupriyadi, S.Pd } \\
\text { (Koordinator } \\
\text { Lapangan) } \\
\text { - Komite Sekolah }\end{array}$ \\
\hline 2 & $\begin{array}{l}\text { Komunikasi } \\
\text { dan Peringatan } \\
\text { Dini }\end{array}$ & $\begin{array}{l}\text { - } \text { Basuki, S.Pd } \\
\text { - Subagyo (Wali } \\
\text { Siswa) } \\
\text { - UMMC }\end{array}$ \\
\hline & Penyelamatan & $\bullet$ Suripto \\
\hline
\end{tabular}

\begin{tabular}{|c|c|c|}
\hline 3 & $\begin{array}{l}\text { Aset dan } \\
\text { Prasarana }\end{array}$ & $\begin{array}{l}\text { - Widodo } \\
\text { - Supriyanto (Wali } \\
\text { Siswa) } \\
\text { - Purwarsi }\end{array}$ \\
\hline 4 & $\begin{array}{l}\text { PPPK dan } \\
\text { Konsumsi }\end{array}$ & $\begin{array}{l}\text { - Tri Wahyuni } \\
\text { - Christiana Katri } \\
\text { - Suratmini } \\
\text { - Darni }\end{array}$ \\
\hline 5 & $\begin{array}{l}\text { Evakuasi dan } \\
\text { Penyelamatan }\end{array}$ & $\begin{array}{l}\text { - Heru Sutrisna, S.Pd } \\
\text { - Paryati, S.Pd } \\
\text { - Wiyono, S.Pd }\end{array}$ \\
\hline 6 & $\begin{array}{l}\text { Pendidikan } \\
\text { Darurat }\end{array}$ & $\begin{array}{l}\text { - Lelita Ranggiana, } \\
\text { S.Pd } \\
\text { - Murti Sunarni, } \\
\text { S.PdI } \\
\text { - Amalia Eva } \\
\text { Yuliastuti } \\
\text { - Dwi } \\
\text { Widarminingsih } \\
\end{array}$ \\
\hline 7 & $\begin{array}{l}\text { Pendataan } \\
\text { Siswa }\end{array}$ & $\begin{array}{l}\text { - Arif Luqman } \\
\text { Hakim } \\
\text { - Vicki Vitria } \\
\text { Ahmad } \\
\text { - Romadi } \\
\text { - Guru Piket/Guru } \\
\text { Mata } \\
\text { Pelajaran/Ketua } \\
\text { Kelas }\end{array}$ \\
\hline
\end{tabular}

\section{SIMPULAN DAN SARAN}

Simpulan

Kesimpulan dari seluruh data yang diperoleh adalah SD Negeri Umbulharjo 2 Cangkringan-Sleman telah memenuhi efektivitas program melalui ketepatan sasaran yakni siswa. Kemudian sosialisasi program dilaksanakan melalui pelatihan guru, simulasi bencana, dan kerjasama dengan pihak lain. Ketercapaian tujuan program dilaksanakan oleh sekolah melalui 
misi, tujuan, dan integrasi ke dalam kurikulum sekolah. Pada pemantauan program sekolah ini bergantung pada monitoring dan evaluasi dari pemerintah. Efisiensi dalam program pendidikan pencegahan dan pengurangan risiko bencana di sekolah ini memanfaatkan sumber daya manusia dalam pelaksanaanya, dibentuknya Tim Sekolah Siaga Bencana dan bekerjasama dengan masyarakat sekitar.

\section{Saran}

Peneliti memberikan saran untuk sekolah dalam sosialisasi program pendidikan pencegahan dan pengurangan risiko bencana agar terus dikembangkan, tidak hanya melaksanakan rutinitas seperti simulasi bencana saja, tetapi dapat melalui kegiatan-kegiatan ekstrakurikuler di sekolah ataupun melalui peringatan hari bumi, hari lingkungan hidup, hari pengurangan bencana alam internsional, dan hari gunung sedunia dengan melibatkan pihak luar selain instansi pemerintah. Kemudian untuk pemantauan program pendidikan pencegahan dan pengurangan risiko bencana, akan lebih baik jika sekolah lebih aktif untuk mengevaluasi mandiri kegiatan program pendidikan pencegahan dan pengurangan risiko bencana setiap tahun ajaran baru, sehingga apabila BPBD ataupun instansi terkait tidak rutin dalam mengevaluasi, sekolah tetap dapat terus meningkatkan program pendidikan pencegahan dan pengurangan risiko bencana tanpa harus menunggu instruksi dari BPBD ataupun instansi terkait.

\section{DAFTAR PUSTAKA}

Amri, A. (2017). Pendidikan Tangguh Bencana. Jakarta: Seknas Satuan Pendidikan Aman Bencana Kemendikbud.

BPK RI. (2007, April 26). Undang-undang No. 24 Tahun 2007 tentang Penanggulangan Bencana. Retrieved Januari 11, 2020, from JDIH BPK RI: peraturan.bpk.go.id/Home/Details/39 901/uu-no-24-tahun-2007

BPK RI. (2010, Oktober 01). Peraturan Daerah Provinsi Daerah Istimewa Yogyakarta No.8 Tahun 2010. Retrieved Januari 11, 2020, from JDIH BPK RI: peraturan.bpk.go.id/Home/Details/17 444/

Budiani, N. W. (2007). Efektivitas Program Penanggulangan Pengangguran Karang Taruna "Eka Taruna Bhakti" Desa Sumerta Kelod Kecamatan Denpasar Timur Kota Denpasar. Jurnal Ekonomi dan Sosial INPUT Vol. 2.

Desfandi, M. (2014). Urgensi Kurikulum Pendidikan Kebencanaan. Sosio Didatika, 191-198.

Dewi, I. K., Sukmanasa, E., \& Laihad, G. H. (2015). Pembelajaran Pengurangan Risiko Bencana Pada Kurikulum 2013 Untuk Jenjang Pendidikan Dasar. Seminar Nasional Pendidikan IPA dan PKLH Program Pascasarjana Universitas Pakuan (pp. 184-191). Bogor: Universitas Pakuan. 
Gunawan, I. (2014). Metode Penelitian Kualitatif Teori \& Praktik. Jakarta: Bumi Aksara.

Konsorium Pendidikan Bencana Indonesia. (2011). Kerangka Kerja Sekolah Siaga Bencana. Jakarta: Konsorium Pendidikan Bencana.

Rahma, A. (2018). IMPLEMENTASI PROGRAM PENGURANGAN RISIKO BENCANA (PRB) MELALUI PENDIDIKAN FORMAL. Varia Pendidikan, 30,111.

Ritaudin, I. (2015, September - Oktober). Analisis Efisiensi dan Produktivitas dari LPTK di Indonesia. Jurnal Elektronik Pendidikan Teknik Elektronika, 4, 7.

Sayidatun Nisa, A. (2019). Optimalisasi Pendidikan Mitigasi Bencana Melalui Penumbuhan Budi Pekerti Dalam Membentuk Karakter Tanggap Bencana. SEMINAR NASIONAL GEOTIK (pp. 177-184).

Surakarta: FKIP UMS.

Septikasari, Z., \& Ayriza, Y. (2018). Strategi Integrasi Pendidikan Kebencanaan Dalam Optimalisasi Ketahanan Masyarakat Menghadapi Bencana Erupsi Gunung Merapi. Jurnal Ketahanan Nasional, 47-59.

Setiawati, K. R. (2019). Manajemen Program Sekolah Siaga Bencana di SMP Negeri 1 Cangkringan .

Setyowati, D., Martuti, N., \& Nugraha, S. (2016). Pendidikan Bencana Banjir (Kesiapan Masyarakat dalam Menghadapi Banjir di Kali Beringin Indonesia dan Sungai Uthapao Thailand). Semarang: CV. Sanggar Krida Aditama.

Sugiyono. (2015). Metode Penelitian Pendidikan. Bandung: Alfabeta.

Sukirno, S. (2006). Pengantar Bisnis. Jakarta: Prenada Media Group.
Sulistiyono, T. (2013). Ilmu Pendidikan. Yogyakarta: UNY Press.

Widjanarko, M., \& Minnafiah, U. (2018). Pengaruh Pendidikan Bencana Pada Perilaku Kesiapsiagaan Siswa. Jurnal Ecopsy, 1-7.

Ditjen Pendidikan Dasar dan Menengah. (2017). Peraturan Menteri Pendidikan dan Kebudayaan Nomor 23 Tahun 2017 tentang Hari Sekolah. Jakarta: Depdikbud

Polres Bantul DIY. (2017). 20 Siswa SD ketangkap basah merokok di sekolah. Diaksesdariwww.tribatanewsbantul.co m/2017/01/20-siswa-sd-ketangkapbasah-merokok-di.html. Pada tanggal 18 Maret 2019, jam 16:21. 